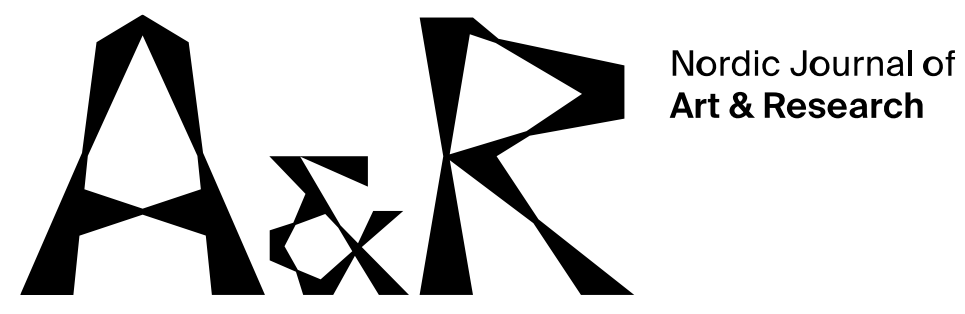

\title{
Practice-led Research in the Art Museum:
}

\section{Research on Education Practices Led by the Practitioners}

\author{
Line Engen ${ }^{1}$ \\ The National Museum of Art, Architecture and Design
}

\begin{abstract}
Society and policy makers are increasingly expecting art museums to be democratic and socially relevant platforms that are inclusive to everyone. To manifest this shift, each institution must draw on the entire spectrum of museal knowledge, not least audience and education knowledge. There has been a history of professional hierarchy and knowledge hegemony inside the art museum, where object-based knowledge has trumped practice-based knowledge and where the education discipline has had a low rank. An important reason for this imbalance has been the great backlog in education research that, among other things, is related to a lack of institutional facilitation and adequate practice-related research methods. Research in art museums has largely operated within traditional art history, but now more and more museums are drawing on other models outside the museum disciplines to develop new research standards. One of the museums that have been transformed by a new outlook on practice and research is Tate, which has developed a practicerelated research method inspired by models within the arts and school systems. In this article I will reflect on the importance of art museums establishing a research framing that ensures efficient interdisciplinary creative processes, reflection and knowledge sharing to create the best practice for the audience. In my argumentation I
\end{abstract}


draw on both the Tate model and my own experience from working at the National Museum in Oslo for over a decade.

Keywords: practice-led research, practice-based research, Tate, art museum, education; knowledge hegemony, professional hierarchy, physical knowledge, museology, curator

\section{Introduction}

By interrogating how research is defined and enacted we can surface, amongst other issues, how the art museum negotiates power and authority, which in turn helps understand how the institution frames its relationship with its publics. (Pringle, 2019b, p. 9)

This article, which is an adaptation of my contribution to the Art in Education seminar in August 2019 in Oslo, Norway, is related to my work in the Research and Development Team for Education at the National Museum in Oslo. ${ }^{2}$ In 2018 I initiated and started a process of investigating and developing a practice-related research alternative to enable education curators to conduct research on their own practice and thereby also help reduce the backlog on education research drawing on the Tate model. The initiative was strongly motivated by my attempt to conduct research on my own practice some years earlier, which made me realize the need for adequate new methods and new perspectives on how knowledge is defined and generated in the art museum (Engen, 2019). The Research and Development Team has a vision for the National Museum to become a leader in developing innovative education methods and research on education, including developing and implementing practice-related research methods. This is also in line with the National Museum's new overarching strategy stating that the museum has a "long-term goal of integrating research into the way we work" (Nasjonalmuseet, 2019). Having been a board member for the Norwegian museum association (Norges Museumsforbund), for the last four years, I have also had the chance to share, develop and discuss these thoughts and issues with colleagues from museums throughout Norway, something that has become a great source of knowledge and understanding (Engen, 2019).

\footnotetext{
2 The R\&D team was developed in 2018 and was a focus area at the National Museum throughout 2020.
} 
A further motivation behind this work is to provide insight into the processes at the art museum from an insider's point of view and thereby contribute to the ongoing dialogue, much inspired and encouraged by the National Museum's new strategic values, which stress openness, courage, innovation, respect and recognition (Nasjonalmuseet, 2019). I also wish to help expand and adapt the format of an academic article to include a larger variation of expressions and methods and to a greater extent include personal and emotional reflections and knowledge. As an "inside worker", I do not have the total overview of the complex and multi-facilitated field involving art, education, museum and research in Norway, and most certainly not internationally. That said, in this article I allow myself to think and reflect from both a personal and an inside perspective, because I think a broader contribution of voices and knowledges is essential to facilitate innovation within this field. An education practitioner in an art museum works on developing concepts and practices both for and with the audience - our field is the platform where audience and art meet and connect. We stand in the messy middle of things, not on the outside. And our "gold" is the closeness to this material, the hands-on experience and the joy and possibility of transforming ideas and theory into practice.

In this article I will argue for the importance of creating a research framework in the art museum, ensuring that the different types of knowledge produced at the museum are recognized and shared both inside the institution and with the wider field outside. In my opinion, such a framework should include three key features: first, a method for interdisciplinary creative processes geared toward exhibitions and audience concepts; second, adequate practice-related research methods that permit museum practitioners to investigate and develop practice; and third, formalized structures for both implementing the new knowledge inside the museum and sharing it with the field outside. This understanding of such a framework is inspired by Tate's research model and by the experience from working as an education curator for over a decade at the National Museum and also conducting practice-related research. In my reflection and argumentation, I also draw on several theoretical perspectives within the fields of museology, educational sciences, sociocultural studies, participatory literature and sociology.

I will begin by discussing how art museums are still struggling to reach a broad audience even though various theories and strategy documents define them as democratic platforms. I will reflect on this paradox in light of the historical lack of research and theoretical frameworks and thus also of a room of action for educators. I will also reflect on the growing trend of participatory practices in art museums. Why is this phenomenon expanding, and why is research important in this development? I 
will then move on to present my own experience with both developing participatory practices and conducting research, before I describe Tate's institutional makeover and research framework. Based on this, I will discuss the format, possibilities and challenges of practice-related research and processes of generating and sharing knowledge in the art museum. Finally, I will summarize by presenting a proposal for a framework for research in the art museum.

\section{Background}

\section{History of hierarchy and lack of communication}

According to new museology, the expectations from society and the concept of the art museum have undergone nothing less than a paradigm shift during the last decades: a shift of focus from object to audience, and thereby also new quality standards (see, e.g., Dysthe, Bernhardt \& Esbjørn). Not only must the artworks exhibited be of great quality, but the museum must also offer high-quality participation practices and be an inclusive museum for everyone (see, e.g., Brenna, 2016). For a long while now, most art museums have to a greater or lesser degree reflected these thoughts in their overarching strategies and visions. But to what extent has this shift been manifested in the actual work inside the museum, and to what extent has the audience noticed this turnaround and benefited from it? And when museology and the theoretical field outside the museum announce a shift, to what extent do they draw on and have knowledge about the reality inside the museum?

Statistics show that fewer people in Norway are visiting art exhibitions now than before the turn of the millennium, a trend also seen in other countries such as the United States (see, e.g., Simon, 2010; Statistics Norway, 2017). Research and audience surveys show that contemporary art is the artform that has the most segmented audience and struggles the most to reach out to the wider public (see, e.g., Gran \& Wedde, 2012; Sifakakis, 2007). ${ }^{3}$ In the National Museum's last ambitious audience survey from 2012, respondents answer that a lack of knowledge makes them feel alienated and inhibits them from visiting the museum (Gran \& Wedde, 2012). To be sure, these findings must be seen against the long-term trend

\footnotetext{
${ }^{3}$ An example of a debate about the experience of contemporary art as difficult and inaccessible in the public discourse is the polemic between a contemporary artist, a cultural journalist and a curator in the Norwegian newspaper Aftenbladet in 2015 (Jølbø, 2015).
} 
of schools de-emphasizing arts and crafts, and in particular new forms of art (Baumford, 2012; Rimstad, 2015). But they must also be seen as a result of art museums themselves failing to develop updated and adapted audience concepts and methods of learning and meaning making, as several studies have suggested (see, e.g., Aure, Illeris \& Örtegren, 2005; Pierroux, 2006, Sifakakis, 2007; Simon, 2010). Despite the announced shift to a constructivist museum model with a strong audience focus, the most common transfer of information to spectators about the art on display has remained largely monological, authoritative and optical-linguistic, in the form of texts on the wall or in leaflets (on the constructivist museum model, see Hein, 2005; see also Dysthe, Bernhardt \& Esbjørn, 2012; Solhjell, 2009). ${ }^{4}$ Moreover, audience surveys and studies show that a large part of the audience perceive both the art and the texts as inaccessible (see, e.g., Bauer \& Pierroux, 2014; Bore, 2017; Choi, 2018; Sifakakis, 2007). ${ }^{5}$

The growing audience focus over a longer period would indicate that the educator's competence would be of the greatest value. Nevertheless, my own experience from working in an art museum for over a decade does not bear this out, and several studies shows that museum educators, to a surprisingly great extent, have retained their low rank in the professional museum hierarchy (see, e.g., Aure, Illeris \& Örtegren, 2009; Charman, 2005; Pierroux, 2006; Pringle, 2019b). In interdisciplinary processes geared toward different museum practices, object-based and art-historical knowledge has to a large extent continued to trump practice-based and educationaltheoretical knowledge and to a higher degree informed the museum's overall direction (Engen, 2019, see also Pringle, 2019b). This, among other factors, has caused a good deal of conflict in the interdisciplinary project work, making the processes and knowledge sharing less effective and curtailing innovation (see, e.g., Pringle, 2019b).

Research and a theoretical framework will always raise the status of a discipline. Art museum research has mostly operated within traditional art history, and there has

\footnotetext{
4 I must emphasize that I am here talking about education practices in the open museum areas for a broad audience, not the practical-aesthetic education geared toward schools and kindergartens in the museum workshops isolated from the exhibition.

${ }^{5}$ According to Professor Boel Christen Scheel, practitioners within the visual arts find it hard to free themselves from cumbersome jargon because they are afraid of losing legitimacy in their own professional group (Bore, 2017).
} 
been neither time, traditions, expectations nor adequate methods for museum educators to attend to practice-related research (Engen, 2019, see also Pringle $2019 b)$. The art-historical discourse has become predominant in the art museum's meaning production. Museum educators have by and large continued to work within an old-fashioned delivery model, supplying the exhibitions with education, texts, programs and so forth, with little or no time and space to analyze and reflect (see, e.g., Pringle, 2019b). Therefore, despite the massive growth of both interest in and literature on the art museum, the practitioners themselves have carried out surprisingly little research on education practices (see, e.g., Nevins, 2018; Pringle \& DeWitt, 2014). Knowledge of the practical and theoretical framing and motivation behind such museum education practices, as explained and reflected on by the practitioners themselves, has only to a limited extent been shared and highlighted either inside or outside the museum. This has contributed to a gap between the museum's own discourses and disciplines, between internal practitioners and external theorists, between practice and theory, and ultimately between the art museum and its audience.

\section{The shift: Audience participation and new forms of knowledge}

Influenced by the rapid technological development and social networking communities, a participatory discourse has been developing in the culture field (see, e.g., Delwiche, 2013; Simon, 2010). Socio-cultural studies of the art museum audience from the last ten years have found that the concept of learning and meaning making, or Bildung, has been radically changed and is now understood more as an individual process within a collective framing (see, e.g., Dysthe, Bernhardt \& Esbjørn, 2012; Rung, 2013; Steier, Pierroux \& Krange, 2015). ${ }^{6}$ Studies show that the audience's personal response to the art and their dialogue with their fellow visitors is one of the main purposes of the museum visit and experience. If the museum's "script" does not match the audience's actual use of the exhibition but builds on the old educational model focusing on an authoritative, monological knowledge transfer, it may lead to a gap between the museum and the audience (Rung, 2013).

\footnotetext{
${ }^{6}$ Bildung, or dannelse in Norwegian, is a frequently used term regarding learning and meaning making processes in Norway and Denmark (see, e.g., Dysthe, Bernhardt, \& Esbjørn, 2012; Rung, 2013). In Norway an updated understanding of the term within higher education has been debated within academia.
} 
Such aspects form the backdrop for one of the of the most prominent and expanding trends in the 21st-century art museum: the emergence of participatory practicalaesthetic activities in open audience areas (Engen, in press). ${ }^{7}$ This is a new form of exhibition education for a large audience, drawing on a completely different concept than the old formula of monological, optical-linguistic information from the museum to the audience. These participation practices may seem similar at first glance, but they are rooted in several different educational and artistic strategies and theories depending on the museum - and not least, they differ in the extent to which they have developed as individual projects or as part of the museum's overall strategy and practice. Leading museums such as Tate and MoMA have gradually established ambitious participation practices on a regular basis (see, e.g., Woon, 2019; Pringle, $2019 b)$. Other museums do the same, varying according to scale and frequency (Engen, in press).

The development of such practices has also challenged the view of how knowledge is produced and what knowledge is in the art museum. More and more art museums have turned to models outside the museum disciplines to develop research standards adequate for their practices, such as action-research models in the educational sector or artistic research (see, e.g., Boomgaard, 2015; Sigfúsdóttir, 2015; Engen, 2019; Pringle, 2019b). One of the pioneers in rethinking research in the art museum, drawing on both these models, is Tate and their research leader, Emily Pringle (Pringle, 2019b). Tate's transformation over a period of approximately ten years involves not only implementing a practice-related method but also an institutional turnaround. This shift must also be seen in connection with the UK's Arts and Humanities Research Council defining Tate as an independent research organization (IRO) in 2006, with an equivalent status as universities to directly apply for national research funding, run doctoral programs and initiate major research projects (Walsh, 2016).

In Norway, the (art) museums are still to a large extent compared to, but not equal to, universities in terms of the form and sharing of knowledge production. The question then is whether it is beneficial for (art) museums to strive toward a university research

\footnotetext{
7 Drawing on Dysthe, Bernhardt and Esbjørn (2012), among others, I choose to use the term "practical-aesthetic education" as a collective noun for this kind of creative activity with an aesthetic dimension or relating to the artistic processes in the art museum.
} 
model. The Norwegian museum association Norges Museumsforbund has repeatedly argued for the importance of museums also attending to research (see, e.g., Ekornes, 2017). Measures aimed at strengthening museum research include developing a publication alternative for research articles and a university-based program for museum workers where they can improve their skills in developing academic articles. But such a research model and definition does not include or fit all the different types of knowledge being produced in today's art museum, with some of them for example largely drawing on artistic processes and methods. Should not the method and form of sharing be adapted to the knowledges that are actually being generated, and not the other way around? There is also the danger that too much focus on individual projects and on writing academic articles as the only research alternative may compromise long-term perspectives of building knowledge in the institution and strengthening the competence and the museum staff.

\section{Development of participation practice and research: the National Museum and Tate}

\section{From pilot to research: a story from the inside}

In connection with a large-scale exhibition of the pioneering Norwegian modernist sculptor Aase Texmon Rygh at the Museum of Contemporary Art in Oslo in 2014, three smaller rooms of the exhibition area were dedicated exclusively to educational purposes. ${ }^{8}$ This new practice gave space and opportunity to examine new ways to engage with a broad audience across socio-cultural differences, interests and background knowledge. The rooms were designed as social zones where people could participate and engage in collective and multisensory learning and meaning making. The rooms were part of the exhibition's permanent and self-contained education, intended for everyone visiting the museum during opening hours. At the time, the museum's educators typically wielded very little influence over the exhibition concept and the physical layout of the rooms, though they did sometimes contribute to various education texts. So, what facilitated such an ambitious pilot education project?

\footnotetext{
8 The Museum of Contemporary Art housed the National Museum's collection of contemporary art until 2017, when it closed in preparation of a move to a new complex for the entire museum (National Museum, n.d.).
} 


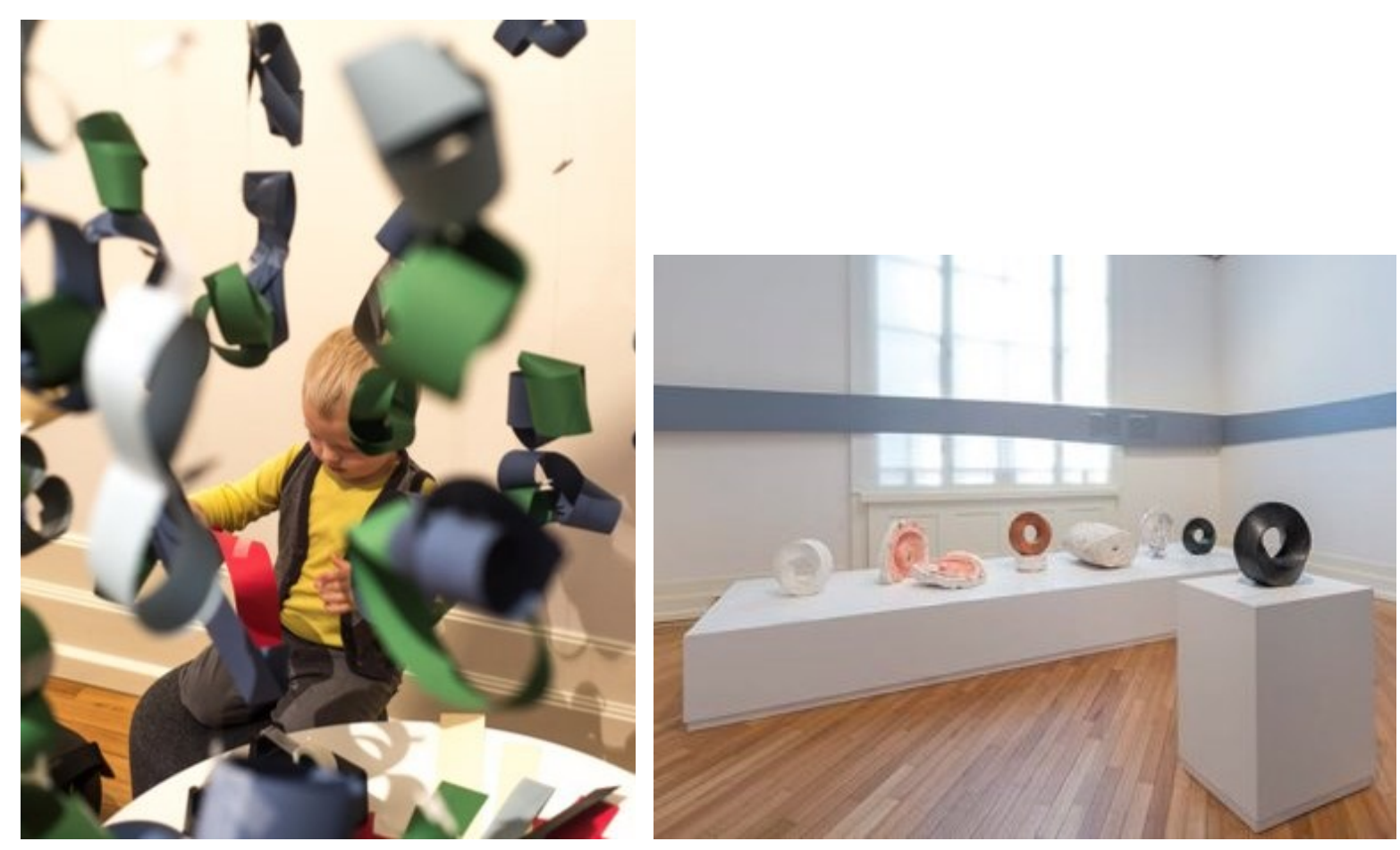

Figures 1 and 2. The first of the three education rooms in the Texmon Rygh exhibition, referred to as the Möbius Room. Museum of Contemporary Art, 2014. Photo: Erik Nilsen

The responsibility for developing the exhibition's content and concept lies with what we at the National Museum in Oslo call "the core group," represented by the discipline's collection curator, ${ }^{9}$ education curator and project manager. But in the development of an exhibition, more people are of course involved - and it varies somewhat which disciplines are actively involved in the creative process, such as for example exhibition design and graphic design, but also conservation, exhibition technique and communication. At this time the museum was testing out the so-called Verktøykassa, or "Toolkit" (Uldall, 2016), a formalized method for the creative, interdisciplinary process of developing an exhibition concept. The Toolkit introduced a new way of thinking and structuring collaborative exhibition development with three different phases: the idea phase, the idea evaluation phase and the exhibition development phase. This helped ensure that the whole core group was involved from the start (which, as already mentioned, often had not been the case) and that the

\footnotetext{
${ }^{9}$ At the National Museum, the position of collection curator was previously called the exhibition curator. The change of title was a result of the new organizational model of 2018 where the collection department was established. (Nasjonalmuseet, 2018)
} 
education and audience knowledge would be considered and discussed in the process and more strongly inform the exhibition concept.
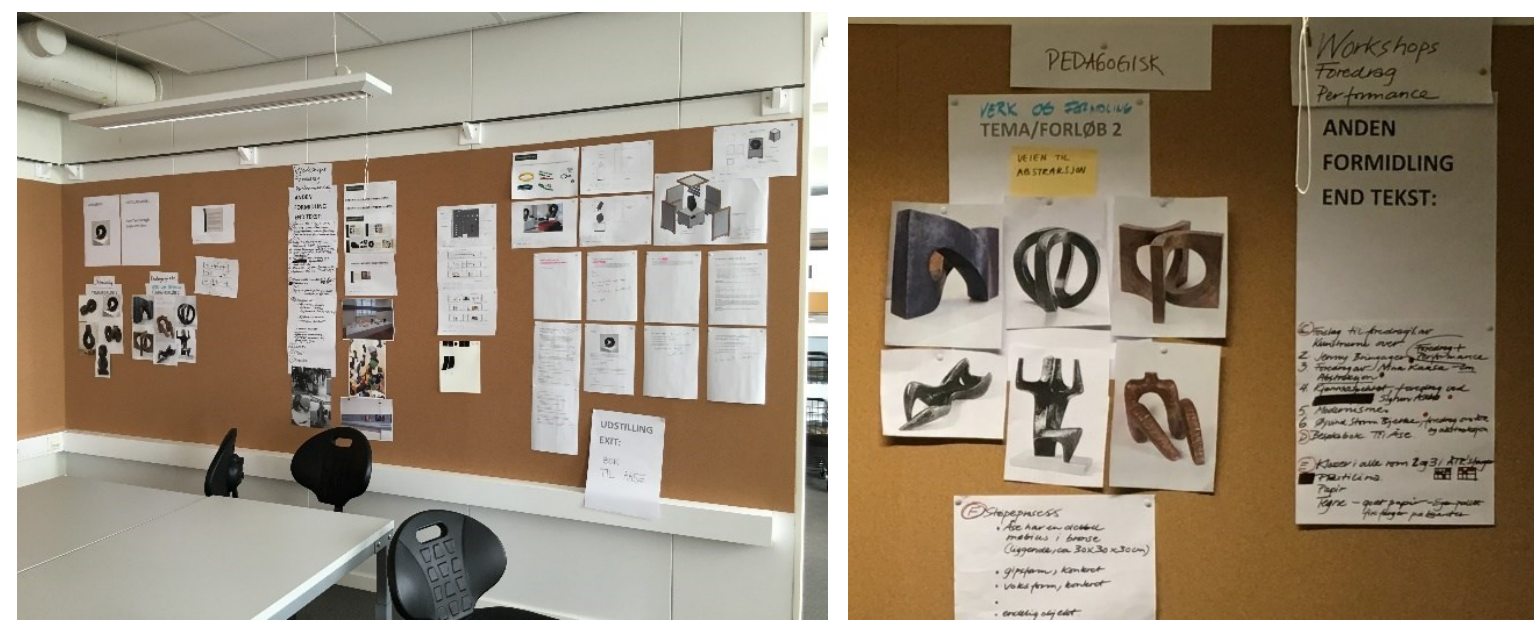

Figures 3 and 4. Working process of the Shape of Eternity touch exhibition with the Toolkit in a National Museum project room. Photo: Ida Strøm-Larsen

This method was introduced by the museum's first education adviser, a new position at the institution. This adviser, who had a great deal of education experience from a major art museum outside of Norway, brought in new thoughts, ideas and knowledge first and foremost to the educators, but with the additional aim of reaching the whole institution and all disciplines involved in creative, interdisciplinary project work. Some project groups chose to test and use the Toolkit, while some, for different reasons, did not. In other words, this cannot be described as an institutional turnaround. But the Texmon Rygh exhibition is an example of a project developed with the Toolkit.

The idea phase consists of several aspects of an exhibition in terms of the audience experience - such aspects could be the exhibition's target groups, the dramaturgy and narrative of the exhibition, the mood of each room, or education concepts. But the toolkit also asks, "What's new about this exhibition?" and thereby encourages an experimental attitude and an awareness about the new knowledge this particular project potentially can generate. In other words, the idea phase could also introduce a research process if research is on the agenda.

The rooms created for the Texmon Rygh exhibition proved to be a hit with the audience and also received a good deal of positive attention from museum colleagues both inside and outside the institution. My experience was that the core group felt pride and a sense of ownership, and we also received very positive feedback from the management for this education initiative. After this exhibition, similar education zones or rooms were developed in almost every temporary exhibition at the Museum of Contemporary Art in Oslo in the following years. 
Something had changed: it became easier for the educators to argue for such space now. After a while, practical-aesthetic education zones and rooms became a sort of consensus - not without occasional discussions and conflicting interests within the project group, but still. ${ }^{10}$ In other words, new knowledge was produced and transferred through practice.
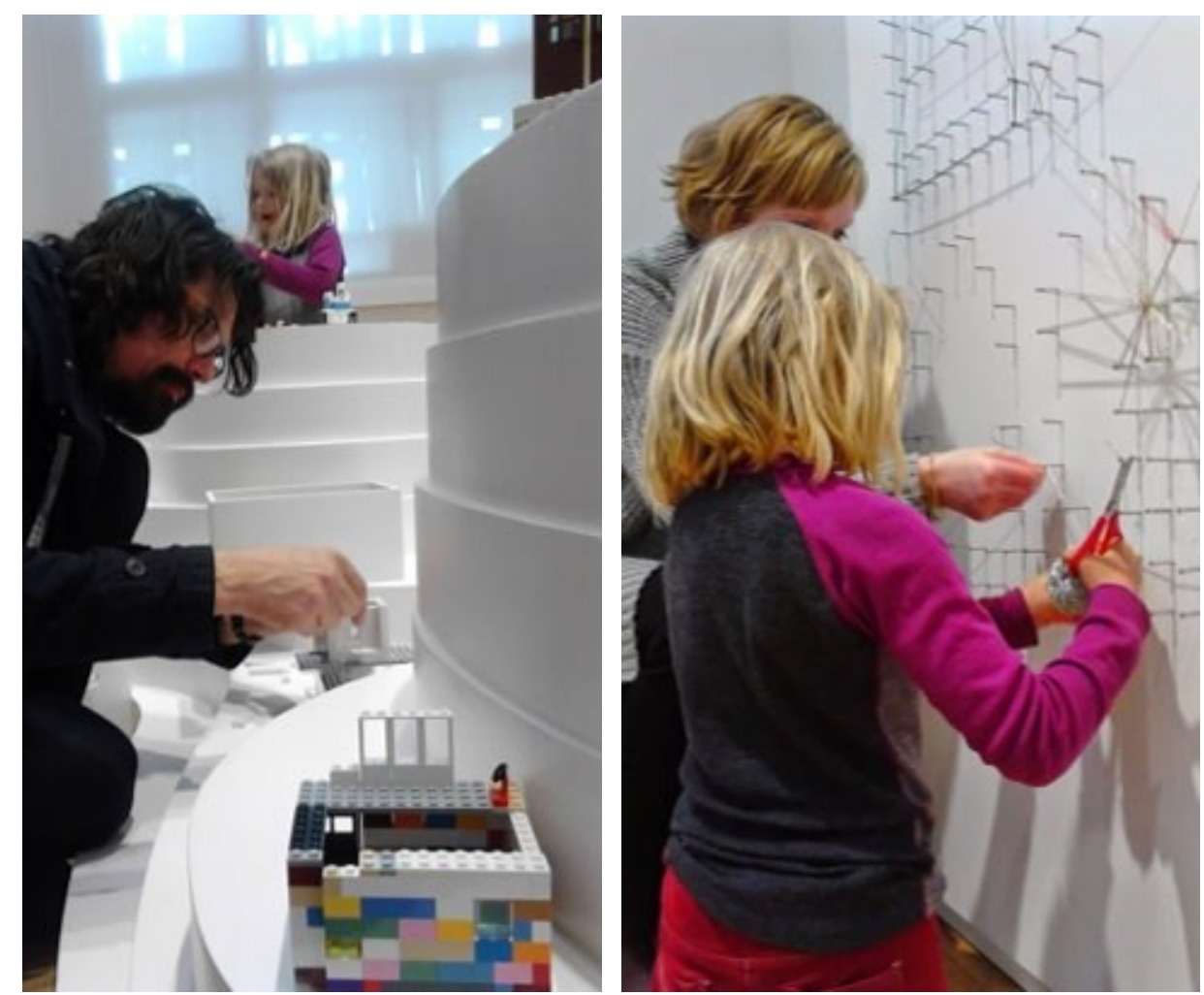

Figures 5 and 6. Education room titled "Create Your Own City" in the exhibition Carlos Garaicoa: The Politics and Poetry of Space. Museum of Contemporary Art, 2015. Photo: Line Engen

The Texmon Rygh education rooms informed one additional pilot project by the National Museum, namely, a touring exhibition with the same artist where visitors were for the first time allowed to touch these original modernist sculptures in a gallery setting (Engen, in press). The core group for that exhibition also chose to use the Toolkit when developing their concept, and this time with even more dedication due to the positive experience of using this method in earlier projects. Furthermore, as an education curator who had been in charge of developing the rooms for the first

10 During the same period, the National Museum's other venues developed similar practices, such as the Drawing Room at the National Gallery, with sculpture drawing activities going on for several years. The National Gallery housed the National Museum's collection of older and modern art until 2019 (National Museum, n.d.). 
Texmon Rygh exhibition, I was now asked to act as exhibition curator, contributing to a natural flow of both knowledge and experience from the first concept. The touchbased exhibition was followed up by researchers at the University of Oslo and ended up receiving a good deal of attention both nationally and internationally (see Christidou \& Pierroux, 2018; Engen, in press; Espeland, 2016; Pierroux, 2017).

Even though new innovative practices had been developed and knowledge had been generated during this period at the National Museum, they had not been framed as research in the museum. This became a problem when the National Museum's exhibition arenas, including the Museum of Contemporary Art, closed down as part of a relocation to a new, joint museum complex that is currently set to open in 2022 . How to communicate and implement this new knowledge and practice through the interdisciplinary processes toward a new museum?
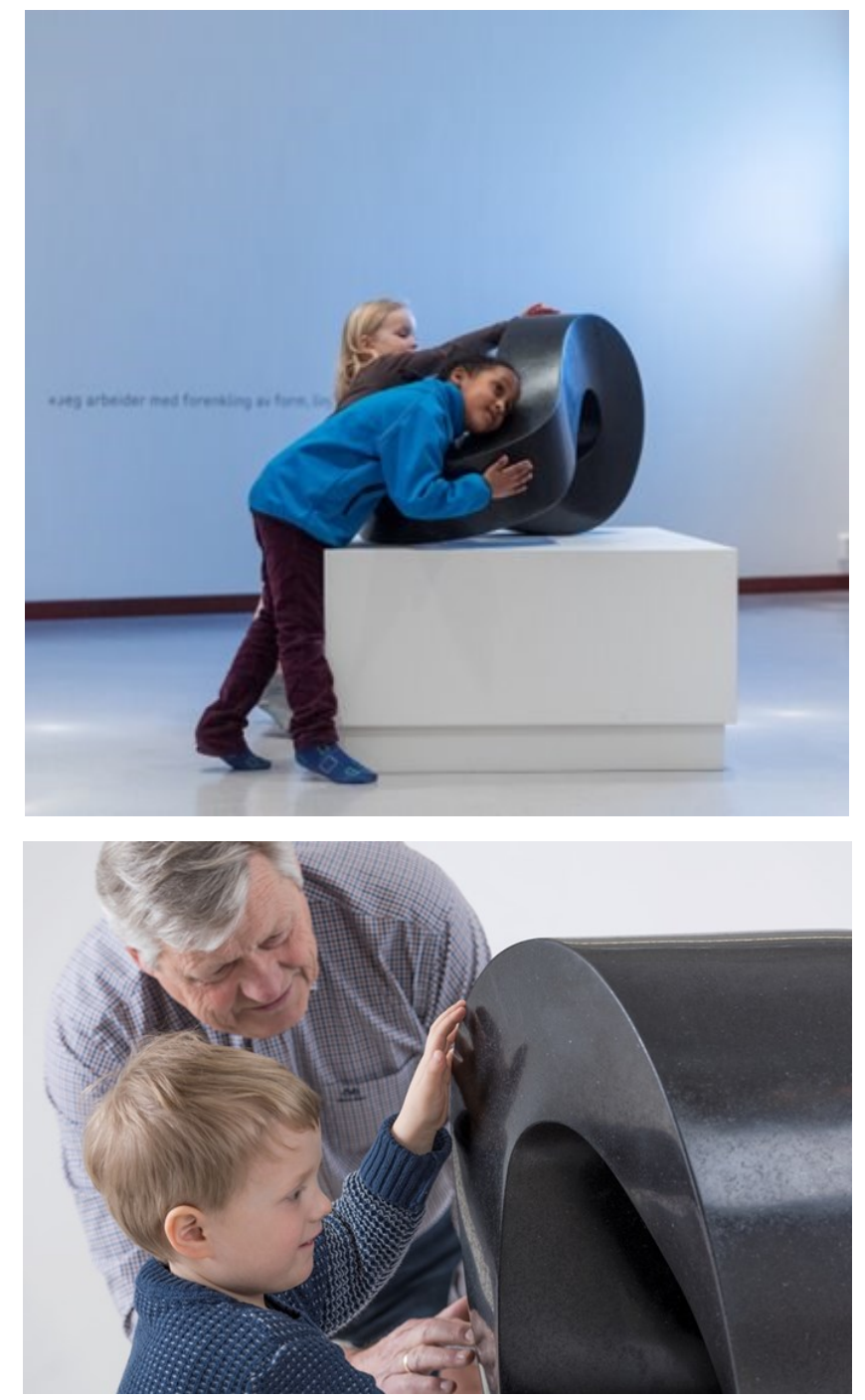

Figures 7 and 8. Audience touching Aase Texmon Rygh's Möbius sculptures. Traveling exhibition Shape of Eternity, 2016-2019. Photo: Annar Bjørgli 
In 2016, the museum hired a new education advisor who came from the theoretical field of education and museology, resulting in an increased focus on theoretical framing and research on education practices. The first adviser contributed from an inside perspective, with a focus on method for interdisciplinary museum work, and now came the outside perspective, with a focus on art education as a professional discipline. The education curators were now encouraged to do research on their own practice.

I began to write a research article that was to be reviewed in an academic museum journal, the only research format and framing I was familiar with as an art historian working in an art museum. I chose the three education rooms at the Museum of Contemporary Art and the National Museum's touch-based travel exhibition as the topic. Intuitively, I started at the very beginning by describing the creative processes behind the two projects and reflecting on and contextualizing them. I also gathered empiric data about the audience response through interviews. This was a highly enlightening process and gave me the opportunity to really reflect on and contextualize the practices. And I was almost shocked by the massive amount of audience studies and literature and research on education in art museums, mostly conducted by researchers outside such museums. This process expanded my knowledge greatly, and I suddenly felt that I was part of a vast field of knowledge and competence. I felt strengthened in my role and ambitions as an education curator.

After sending the first draft to a museum journal, however, their feedback was that I should do the very opposite, namely, create distance to the material. This feedback reflects a traditional research mindset where scholars should examine their material with detachment and objectivity. I say this not as a critique of the journal: the article they had received was a text without any discussion or information about research methods, for example. But it is interesting to notice that instead of guiding me to take an inside perspective, which would engender much-needed insight into museum processes, I was encouraged to take the standard outside perspective. For a long while, I strove to construct an external and more objective perspective and research design. The education adviser position had been discontinued, and the National Museum was in the middle of a reorganization, so I was suddenly on my own with my research project. I realized that as an art historian working at a museum as an education curator, I had neither the experience and methodology nor a framework within my institution to conduct such research on my own practice.

The next phase of this research process then began, which took form more as a metalevel: How to carve out a space and format where I can reflect on and share 
knowledge about this practice? How did other art museums conduct research on their own practice? Tate's new research model, communicated and explained in several forums by their research leader Emily Pringle, became a guiding light and a new possibility to maintain the closeness to the material and acknowledge the value of the inside perspective.

\section{The Tate turnaround and practice as research}

I have now recounted how the new participatory practices at the National Museum were largely developed through personal initiatives among the educators and first later became objects of research. The story about the emergence of such new education practices at Tate is in many ways quite the opposite. The practices themselves are not necessarily very different, but the framing is.

In 2006, Tate and some other national museums in the United Kingdom were defined as independent research organization (IROs) by the Arts and Humanities Research Council, a new research body created one year earlier. At the core of the council's strategies to support and develop arts and humanities research was also an understanding of and response to the changing conditions of knowledge and the changing locations of knowledge production (Walsh, 2016). In 2010, Emily Pringle, who had just finished a PhD in art education with a focus on the relationship between artistic knowledge and practice, teaching and learning in the contemporary art museum, was appointed head of learning practice and research at Tate in London. Her job was to support the strategic development of research-led practice and initiate and manage research and evaluation programs within the Learning Department across Tate Britain and Tate Modern.

The implementation into programming was framed by its ambitious title Transforming Tate Learning (Pringle, n.d.-b). The director of Tate National, Caroline Collier, goes straight to the core of the historical problem concerning professional hierarchy when she explains the motivation behind this transformation:

The principles have been to integrate evaluation and reflection into everyday practice (action research) and to be open to critique, seeking out feedback and interrogation. This confident approach has led to programmes and projects of quality and impact. It has also freed Learning from the confines of marginal departments and made it a core concern of the organisation. Learning with art is now widely recognised to be the primary role of Tate. (Pringle, n.d.-b, p. 2) 
One of the pilot projects in Transforming Tate Learning was Open Studio at Tate Modern, which consisted of different participatory and practical-aesthetic activities not unlike the practices at the Museum of Contemporary Art (see figs. 1, 2, 5 and 6).
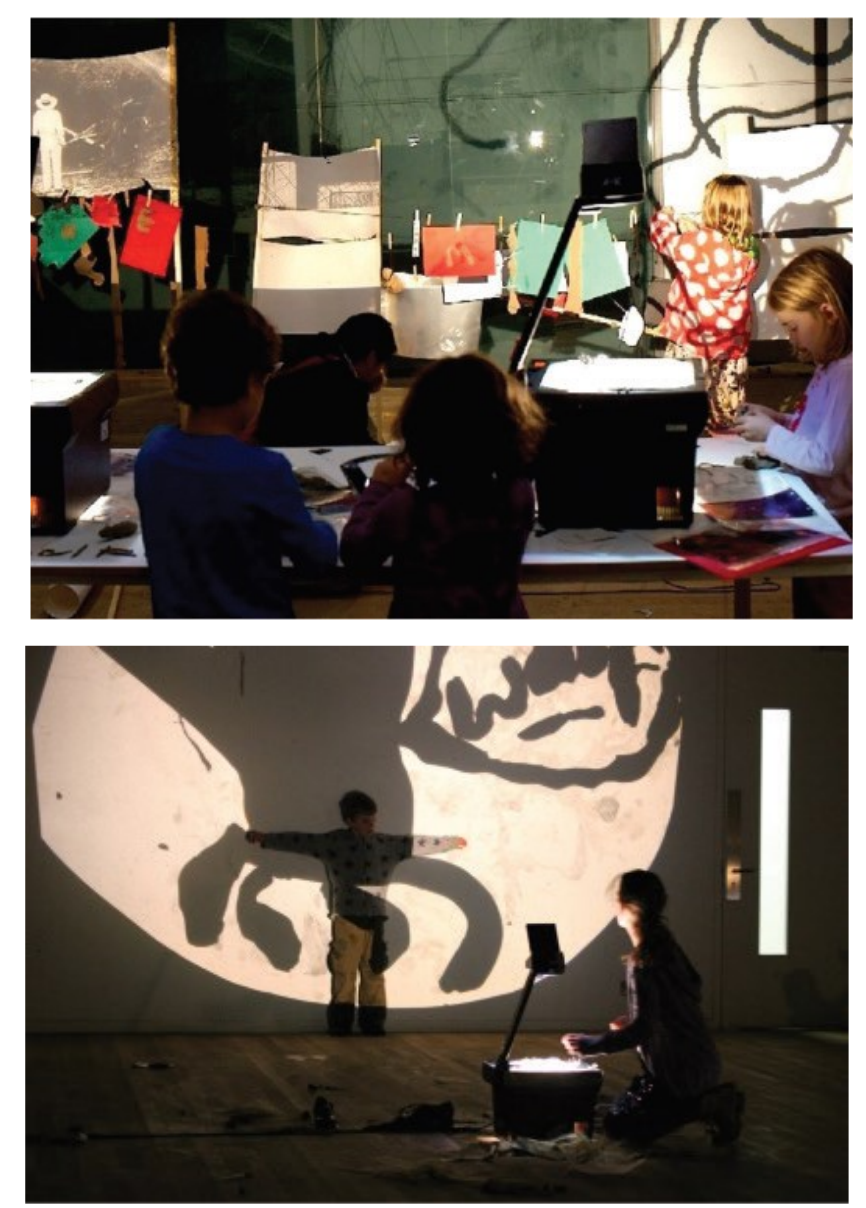

Figures 9 and 10. Figure 9 'The Open Studio'. Copyright Tate Photography. Figure 10 'The Open Studio'. Copyright Susan Sheddan.

With the ongoing Tate Exchange program at Tate Modern, which started up in 2016, the institution has brought this participatory strategy to a new level. Here the audience is invited to participate in the programming together with the museum staff, and the project has an entire floor at its disposal. Tate Exchange is framed as an ambitious research project in collaboration with several external partners. In this period, Pringle also launched the practitioner researcher blog called Practitioner Research in the Art Museum (PRAM), which "looks at how research is undertaken in art museums today and by whom and explores how we might expand on current models to re-shape and broaden our understandings" (Pringle, n.d.-a). In 2019 Pringle was appointed head of research for Tate as a whole and not "just" the learning department, and in her book from the same year, Rethinking Research in the 
Art Museum, she explains, discusses and reflects onthe new method and model (Pringle, 2019b).

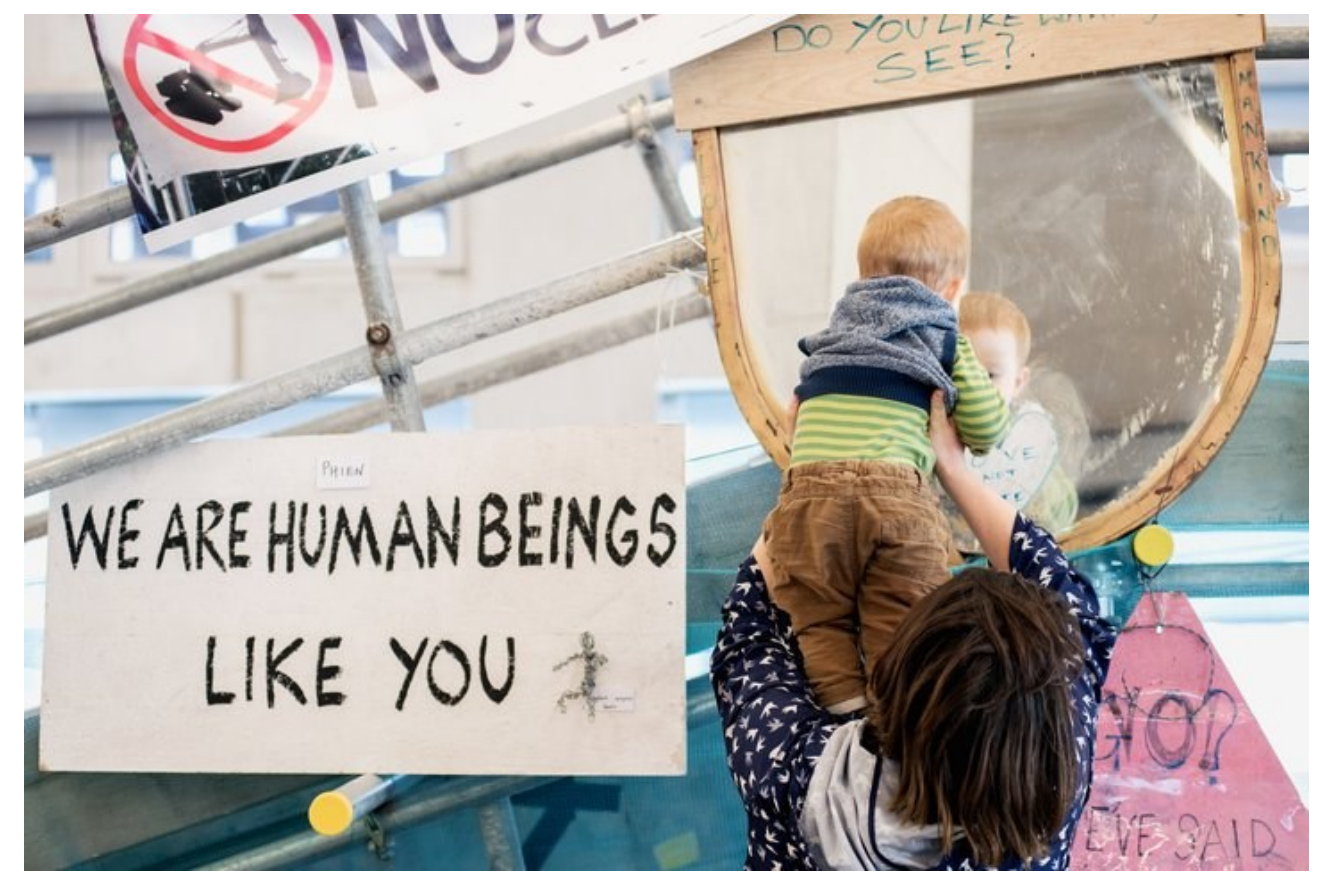

Figure 11. Dale Farm, Tate Exchange. Photo: Alex Wojcik

So, what does this new more practical approach to research at Tate entail? Pringle draws on several researchers and disciplines in her theoretical discussion and argumentation for why and how a practice-related research method should be used in an art museum such as Tate. A core reference is Linda Candy, who distinguishes between two types of practice-related research, namely, practice-based and practiceled (Candy, 2006; Engen, 2019, Pringle, 2018a). If a creative artifact forms the basis of a contribution to knowledge, the research is practice-based, which is the preferred method within artistic research. If, on the other hand, the research leads primarily to new understandings about practice, it is practice-led. In many regards, practice-led research is in line with action research, with an expectation that both form and content are open to constant reappraisal and, potentially, significant change. The preferred method in the school system is action research (Ulvik, 2016.) Pringle (2019b) argues that gallery learning activities involve "a combination of both practicebased and practice-led research" and "generating new knowledge both through and about practice" (p. 71).

Tate and Pringle initially used the term "practice-led" but have over time landed on the term "practice as research" (PAR), which stresses that the practice itself is seen as research. I interpret this choice of term as an adjustment to the overall view of knowledge and ambition within Tate Learning. Pringle (2019b) interviewed and talked 
to her education colleagues about their attitudes toward and motivation for doing research, and she found that their main reason is to enrich and improve practice, rather than to conduct academic research. Furthermore arts-based education, where the use of artistic skills, processes, and experiences is a primary tool in the learning process, stands strong at Tate. (Pringle \& DeWitt, 2014)

Pringle (2019b) states that "whereas in the past the written text was considered the only credible scholarly expression, more recently there have been moves to recognise a range of research outcomes, from films to workshops, from exhibitions and displays to changes in policies and practices" (p. 13). In Tate Learning, she says, the term "practice as research" (PAR) is used generously and encompasses a variety of knowledge-generating initiatives, ranging from an expanded form of reflective practice to large-scale research-led programs (Pringle, 2019b, pp. 71-72). Pringle (2019b) also stresses that the method "recognises the situated, personal and emotional and acknowledges the interconnections between individual subjectivities and external phenomena but does not privilege the objective over the intuitive" ( $p$. 73).

Parallel to this work, Tate also produces Tate Papers, an online research journal "that publishes scholarly articles on British and modern international art, and on museum practice today." This publication channel is, as it seems to me, a traditional academic research journal with peer-reviewed articles, mostly focusing on objects and using art-historical research methods. In other words, different disciplines have their own channels and methods for knowledge production and sharing, also at Tate. How does this divide play out in interdisciplinary processes at the institution, in regard to exhibitions or other audience practices? In her writings, Pringle has highlighted the challenges of such project work in terms of hierarchy and power. But she also underscores that agreeing on research questions works as a type of method for the creative interdisciplinary project work at Tate (Pringle, 2015). Moreover, she stresses the importance of this work being a safe zone where everyone can express their opinion.

\section{Discussion}

In several of her publications on different platforms, Pringle reflects on and explains the practice as research (PAR) method, the institutional turnaround at Tate, organizational challenges and theoretical frameworks. As I see it, she has done a major and priceless work of knowledge sharing and enlightenment. That said, I have experienced that as an external professional colleague it can be a bit difficult to gain insight into how the method enfolds in practice. The research conducted at Tate is 
shared through several formats such as evaluation reports or more experimental and physical practice-based research, but except for Pringle's reflections on this work, few academic articles are available. I have been searching in vain for articles written by education practitioners such as myself - that is, by people working "on the floor" at Tate within this model and being part of the research, sharing their reflections and giving insight into the process.

The difficulty in finding relevant examples has made me wonder whether the format of an academic, peer-reviewed publication is an adequate or even possible way to frame and share such practice-related research in an art museum. My own experience with this format is that the process has been difficult, with material that consists of personal reflections, theory and empirical data being forced into an academic article format and with the practice-led method as a sort of alibi. Thus, as I interpret it, the PAR method at Tate doesn't necessary include my interpretation of a research-related method in an art museum in the form of an academic article. Is this a problem, and do we need such articles?

The time aspect is a huge factor in conducting research within the (art) museum, and as I read and understand Pringle, time is most certainly a factor in the way the research model at Tate is organized: everyone can participate and contribute with their knowledge, even if there is little or no time in the daily work to sit down for longer periods and reflect. Pringle discusses the time issue in several of her texts, and in one blog post she addresses the leaders at the organization directly:

What my experience and research has told me is that without question the main factor that prevents practitioners doing research is their perceived lack of time. I have found that almost without exception people are keen to research, reflect and take time to learn, yet they can struggle to build this into their practice. Too often they are overwhelmed by the practical and administrative aspects of their roles, which are perceived to take priority. Practitioners want time to share problems and insights and consider "what if" questions together as part of their working day. And they want their organisations to acknowledge the importance of the thinking that is required to do their work effectively, by not overloading them with tasks or programming.

It is the responsibility of leadership in the first instance not to overload staff with programming tasks that leave no time for more considered enquiry. Associated with this is the need for leaders to make sure there 
are adequate resources to undertake the work the organisation wishes to do. And finally, leaders can play a key role in encouraging staff to take the time needed, by creating spaces for reflection and sanctioning formal research time away from the day to day routines. (Pringle, 2018b)

I agree with Pringle, and I think that to further minimize the hierarchy both inside the museum and between the museum and the outside research field, as well as to strengthen the educator's competence, time and room for reflection and knowledge sharing is crucial. This can be done not only by contributing to collective research projects but also by conducting research of one's own, perhaps by writing an academic article (if that is an interesting format) or conducting research within a more practice-based or practice-led format.

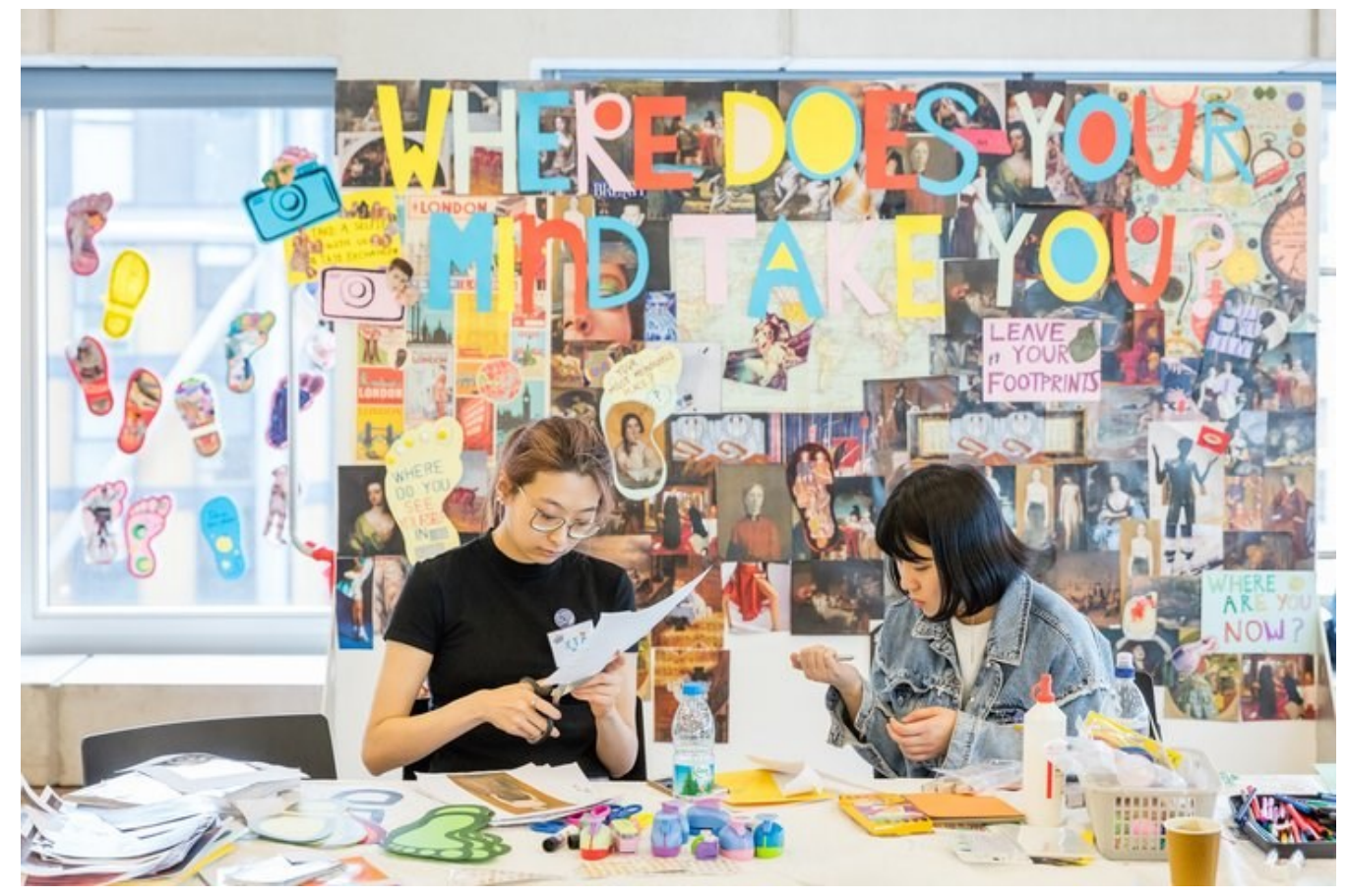

Figure 12. The Museum of Things That Don't Stand Still workshop, with the University of Westminster at Tate Exchange, May 14-17, 2019. Photo: Dan Weil

I consider Tate's focus on and investigation of the physicality of research, physical forms of knowledge, to be very important also when considering the trend and growth of practical-aesthetic education in the art museum. This also touches upon the core of the difficulties that some of my colleagues and I faced when trying to formulate and convey the knowledge we had gained by developing education rooms and zones in the exhibition areas at the Museum of Contemporary Art and in other of the National Museum's venues before the museum closed down in 2017-2018 (see figs. 1, 2, 5 and 6). 
Looking at the development and sharing of new practice and knowledge taking place at the Museum of Contemporary Art in 2014-2017 in retrospect, I would argue that this process resembles action research in terms of generating new knowledge that improves practice. During this period, practical-esthetical practices were established for almost every temporary exhibition. The new knowledge had mainly been developed through and manifested itself in the practices themselves. We had some documentation and could argue for the audience response and set them in connection with international trends, but we experienced difficulties in commutating this expression and form of knowledge due to the existing view of knowledge in the institution. This is an issue Pringle also experienced in regard to her own education colleagues on the floor, whose "expertise was not understood or fully acknowledged and too often remained hidden or tacit" $(2019 \mathrm{~b}, \mathrm{p} . \mathrm{72})$ Concerning her own experience of introducing new practices and research methods at Tate, Pringle notes that

the embedded practice as research and collaborative forms of action research that we were piloting within Learning were sometimes met with a degree of perplexity by colleagues, who initially found it hard to square the methodologies and expressions of research that emerged from these processes with the model of research that has dominated arguably since museums first came into existence. I kept stumbling into unspoken hierarchies of knowledge and seemingly agreed ways of understanding research that appeared in my mind to fit uncomfortably with the way the twenty-first-century art museum worked and its ambitions to be more open and discursive. (Pringle, 2019b, preface)

Critical museologists, sociologists and others have criticized art museums for being undemocratic and exclusionary institutions that wish to appear neutral but are not (see, e.g., Bourdieu \& Darbel, 1991). This has particularly concerned the selection of artists and representation. But what about these new forms of education practices can they be considered as neutral zones or environments? They are perhaps meant for a broad audience, but they are all the same built on certain ideas and, as highlighted above, motivated by personal experiences as well as theory. An important aspect of participatory practices is to open up and become informed by the audience, and evaluation is required in practice-led research or PAR, as explained by Pringle (2019a). According to Victoria Walsh (2016), the flow of knowledge and transparency between institutions means this is no longer an issue. Nevertheless, the research itself must also be evaluated and tested by researchers and others outside the 
museum. The knowledge must therefore be shared in many ways and expressions that may be read or received in different disciplines.

I would argue that we need both the reflection on the research model and museum work, as done by Pringle and others, but also reflection on individual practices in an academic format. That said, I think the format of the research article must be adjusted to the knowledge being produced inside the museum. We cannot expect that museum workers with a different expertise will strive toward the same research design and methods as university researchers, nor is this even desirable or appropriate. As stressed several times throughout this article, it is my opinion that the method must be adjusted to the type of knowledge, and not the other way around. In my opinion, is not efficient to operate with an A and B team within the field of (art) museum research, either inside the museum or between the research produced inside and outside. It should go without saying that the knowledge generated in the museum is just as important for facilitating innovation and best practice as the knowledge generated outside, but also that the different knowledges generated inside the museum are of equal value. As the Tate model and the research models in the school system and within artistic research have shown, the various methods exist - we just have to use them and make them ours. I also think we have to work on more low-threshold communication forms.

I think Pringle's blog, Practitioner Research in the Art Museum (PRAM), is an excellent example. As mentioned, professional hierarchy and knowledge hegemony have led to a good deal of pent-up frustration at museums, including my own. There is also an enormous need to share experiences and new knowledge in this expanding and constantly changing field. With her blog, Pringle has created a forum where different topics can be discussed more freely. I think this sort of platform is an important contribution to the communication flow and knowledge sharing and professional growth and "ventilation."

\section{Summing up}

I initiated this article by defining a research framing drawing on the Tate model and experiences from the National Museum that could help improve and ensure the flow of knowledge inside and outside the museum. The first feature of this framing is a method for interdisciplinary creative processes geared toward exhibitions and public outreach events. Both the examples from the National Museum and Tate illustrates that this is a significant aspect for knowledge flow and facilitating innovation. In his book The Community of Disagreement, the sociologist Lars Laird Iversen draws on studies from different disciplines to argue that a formal method is required to remove 
the creativity-inhibiting link between idea production, idea evaluation and selfpresentation (Iversen, 2014). Iversen also highlights that it is not necessarily the most intelligent person - or as I would reformulate it, the best rhetorician - who has the best idea, but that the idea in question is more persuasively justified.

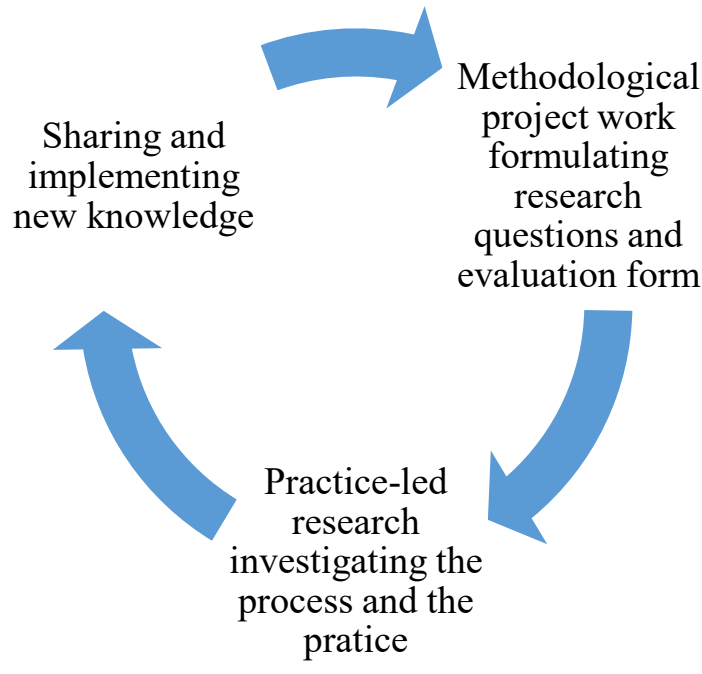

Figure 13. Research framing in the art museum.

According to Iversen, an important aspect of facilitating this real sharing of ideas, where everyone contributes across disciplines and expressions, is the dividing into an idea phase and a phase for evaluating ideas, as is the case for the National Museum's Toolkit. As I see it, this aspect was most certainly a factor in the process of letting new forms of knowledge inform the exhibition and audience practices in the two examples from the National Museum (see figs. 1, 2, 7, 8). But as illustrated above, the Toolkit does not insist on the project group developing research questions or deciding on how to evaluate these new practices, which are the key moments in the PAR model at Tate. I would therefore argue that a combination of these aspects of PAR and the Toolkit could form a fruitful alternative for a method for the interdisciplinary project work in the art museum (see fig. 13).

The second feature is adequate practice-related research methods that permit museum practitioners to investigate the practice and finally, which is the third feature, share the new knowledge both inside and outside the museum. These two features are closely interconnected. In my own research and my work on developing adequate research alternative at the National Museum, I have chosen the term practice-led. As this article has illustrated, there are several names for these practice-related methods, and as Pringle stresses, the nuances are small, and the educating practices in the art museum involve gaining new knowledge both through and about 
practice and are therefore a combination of practice-based and practice-led. That said, "practice-based" and "PAR" are more often used in relation to artistic or physical knowledge. Although a major part of the knowledge production in the examples cited in this article was developed through practice itself, the reflection and contextualization were conducted through the academic article format outside that practice, but nevertheless led by the practice. In this article I have illustrated the need for establishing a greater variety of practice-adequate research methods, and these depend both on the type of knowledge being produced and the process of developing it.

It seems to me that the Tate model, which includes both the article publication channel and several research forms within the PAR model, is a broad and good solution. The only thing I miss is the very format that I am trying out myself: the academic article format with a practice-led research method. I wish that more colleagues with "on the floor" experience would use this format to reflect on the practice in their own institutions and thereby also help adjust and broaden the academic article format. Several of my education colleagues at the National Museum are currently reflecting on their own practice in the format of research articles as we speak (see, e.g., Eek Jensen, 2019; Engen \& Christensen-Scheel, in press). Hence, unlike most of the education staff at Tate, there is a desire among the education staff at the National Museum to contribute with academic articles as well. Thus, my definition of practice-led research includes not only sharing new knowledge through an adjusted and extended research article format, but also a practice- or more "action research"-based approach where new knowledge is generated and shared through practice and seeks to improve this practice. Both expressions of new knowledge are hence deemed to be equally worthy and important for creating innovation and the best practice for the audience.

\section{About the author}

Line Engen is education curator and researcher at the National Museum of Art, Architecture and Design in Oslo. She has a cand. philol. degree in Art History from the University in Oslo (2006). Engen har been a board member of the Norwegian museum association (Norges Museumsforbund) since 2017. She is currently editing the anthology Formidling i nordiske kunstmuseer (Education in Nordic art museums) together with professor Boel Christensen-Scheel. 


\section{References}

Aure, V., Illeris, H., \& Örtegren, H. (2009). Konsten som läranderesurs: Syn på lärande, pedagogiska strategier och social inklusion på nordiska konstmuseer. Skärhamn, Sweden: Nordiska akvarellmuseet.

Bauer, D. \& Pierroux, P. (2014). Expert and adolescent interpretive approaches in a national art museum. Museum Management and Curatorship, 29(3), 260-279. https://doi.org/10.1080/09647775.2014.919162

Baumford, A. (2012). Arts and cultural education in Norway [PDF file]. Retrieved from https://kunstkultursenteret.no/wp-content/uploads/2019/01/Arts-and-CulturalEducation-in-Norway-2010-2011.pdf

Boomgaard, J. (2015, December). The Museum as location of research: The creator doctus model. Paper presented at Between the Discursive and the Immersive: A Symposium on Research in 21st Century Art Museums, Louisiana Museum of Modern Art, Humblebæk, Denmark.

Bore, K. K. (2017, May 31). Hvordan skal vi lære å snakke om kunst? Morgenbladet. Retrieved from https://morgenbladet.no/portal/2017/05/hvordan-skal-vi-laeresnakke-om-kunst

Bourdieu, P., \& Darbel, A. (1991). The love of art: European art museums and their public (C. Beattie \& N. Merriman, Trans.). Oxford, England: Polity Press.

(Original work published 1969).

Brenna, B. (2016). Kvalitet og deltakelse i museer. In K. O. Eliassen \& $\varnothing$. Prytz (Eds.), Kvalitetsforståelser: Kvalitetsbegrepet i samtidens kunst og kultur (pp. 36-52). Oslo, Norway: Norsk kulturråd. Retrieved from http://www.kulturradet.no/vis-publikasjon/-/kvalitetsforstaelser

Candy, L. (2006). Practice based research: A guide [PDF file]. Retrieved from https://www.creativityandcognition.com/resources/PBR\%20Guide-1.12006.pdf

Charman, H. (2005). Uncovering professionalism in the art museum: An exploration of key characteristics of the working lives of education curators at Tate Modern. Tate Papers, 3. Retrieved from https://www.tate.org.uk/research/publications/tate-papers/03/uncoveringprofessionalism-in-the-art-museum-exploration-of-key-characteristics-of-theworking-lives-of-education-curators-at-tate-modern

Choi, D. (2018, October 11). Blir kunsten utilgjengelig av ekspertspråket? Subjekt. Retrieved from https://subjekt.no/2018/10/11/blir-kunsten-utilgjengelig-avekspertspraket/ 
Line Engen. Practice-led research in the art museum

Christensen-Scheel, B. (2019). Education for a new museum. Oslo, Norway: Nasjonalmuseet for kunst, arkitektur og design.

Christidou, D., \& Pierroux, P. (2018). Art, touch and meaning making: An analysis of multisensory interpretation in the museum. Museum Management and Curatorship, 34(1), 96-115. https://doi.org/10.1080/09647775.2018.1516561

Delwiche, A., \& Henderson, J. J. (Eds.). (2013). The participatory cultures handbook. New York, NY: Routledge.

Dysthe, O., Bernhardt, N., \& Esbjørn, L. (2012). Dialogbasert undervisning: Kunstmuseet som læringsrom. Bergen, Norway: Fagbokforlaget.

Eek Jensen, J. (2019). Inn i bildet: Fra rollen som betrakter til rollen som aktør. Nordic Journal of Art and Research, 8(1). https://doi.org/10.7577/information.3596

Ekornes, G. M., \& Ramskjær L. (2017, October 9). Styrk forskningen i alle museene! Forskerforum. Retrieved from https://www.forskerforum.no/styrk-forskningen-ialle-museene/

Engen, L. (in press). Interaktiv sanselig tilnærming til modernistisk skulptur: Fra formidlingsstrategi til utstillingskonsept. Norsk museumstidsskrift.

Engen, L. (2019, September, 27). Praksisledet formidlingsforskning. Museumsnytt. Retrieved from https://museumsnytt.no/praksisledet-formidlingsforskning/

Engen, L., \& Christensen-Scheel, B. (Eds.) (in press). Formidling i nordiske kunstmuseer. Trondheim, Norway: Museumsforlaget.

Espeland, A. E. (2016). Nå får du lov å ta på kunsten. NRK. Retrieved from https://www.nrk.no/rogaland/na-far-du-lov-a-ta-pa-kunsten-1.13179499

Gran, A.-B., \& Wedde, E. (2012). Publikum - hvem, hva, hvorfor?. Oslo, Norway: Nasjonalmuseet for kunst, arkitektur og design. Retrieved from http://norskpublikumsutvikling.no/assets/insights/nasjonalmuseet-publikumhvem-hva-hvorfor-publikumsundersokelse-mars-2012.pdf

Hein, G. E. (2005). Learning in the museum. London, England: Routledge.

Jølbo, D. M. (2015, June 10). Myten om den vanskelige samtidskunsten. Aftenbladet. Retrieved from https://www.aftenbladet.no/meninger/i/6BEw0/myten-om-denvanskelige-samtidskunsten

Nasjonalmuseet. (2019). Strategi 2020-2025. Retrieved from https://www.nasjonalmuseet.no/om-nasjonalmuseet/styret-organisasjon-ogansatte/nasjonalmuseets-strategi-2020-2025/

Nasjonalmuseet. (2018). Arsmelding for Nasjonalmuseet 2018. Retrieved from https://www.nasjonalmuseet.no/contentassets/98adac84980c4555ae99de8a5 ed00e80/arsmelding-2018-materie no digital korr21.2.2020.pdf 
Line Engen. Practice-led research in the art museum

National Museum. (n.d.). Former locations. Retrieved from

https://www.nasjonalmuseet.no/en/about-the-national-museum/formerlocations/

Nevins, E. (2018). On the floor: Museum teaching techniques in the 21st century. Journal of Museum Education, 43(4), 287-290.

https://doi.org/10.1080/10598650.2018.1529343

Pierroux, P. (2006). Meaning, learning, and art in museums: A situated perspective [Unpublished doctoral dissertation]. University of Oslo, Oslo, Norway.

Pierroux, P. (2017). Analyzing embodied interpretation and touch in a sculpture gallery. Paper presented at the annual College Art Association (CAA) Conference, New York, NY.

Pringle, E. (n.d.-a). About me - Emily Pringle [Blog post]. Retrieved from https://practitionerresearchintheartmuseum.com/about/

Pringle, E. (Ed.). (n.d.-b) Transforming Tate Learning [PDF file]. Retrieved from https://www.tate.org.uk/search?q=Transforming+Tate+Learning

Pringle, E. (2015, December). Constructing the practitioner-researcher within the art museum. Paper presented at Between the Discursive and the Immersive: A Symposium on Research in 21st Century Art Museums, Louisiana Museum of Modern Art, Humblebæk, Denmark.

Pringle, E. (2018a). Developing the practitioner-researcher within the art museum. Tate Papers, 29. Retrieved from

https://www.tate.org.uk/research/publications/tate-papers/29/developingpractitioner-researcher-within-art-museum

Pringle, E. (2018b, November 11). Supporting practitioner-led research in the art museum - what can leaders do? PRAM. Retrieved from https://practitionerresearchintheartmuseum.com/?s=leaders

Pringle, E. (2019a). Creative evaluation and gallery education: Moving beyond an accountability model. In B. Christensen-Scheel (Ed.), Education for a new museum (pp. 117-145). Oslo, Norway: Nasjonalmuseet for kunst, arkitektur og design.

Pringle, E. (2019b). Rethinking research in the art museum. London, England: Routledge.

Pringle, E., \& DeWitt, J. (2014). Perceptions, processes and practices around learning in an art gallery. Tate Papers, 22. Retrieved from https://www.tate.org.uk/research/publications/tate-papers/22/perceptionsprocesses-and-practices-around-learning-in-an-art-gallery

Rimstad, A. (2015). Teikn- og meiningsskaping i studentars arbeid med installasjonar [Unpublished doctoral dissertation]. University of Oslo, Oslo, Norway. 
Rung, M. H. (2013). Negotiating experiences: Visiting Statens Museum for Kunst [Unpublished doctoral dissertation]. Leicester University, Leicester, England.

Sifakakis, S. (2007) Contemporary art's audiences: Specialist accreditation and the myth of inclusion. European Journal of Cultural Studies, 10(2), 203-223. https://doi.org/10.1177/1367549407075908

Sigfúsdóttir, Ó. G. (2015, December). What museum researchers can learn from artistic researchers, and vice versa. Paper presented at Between the Discursive and the Immersive: A Symposium on Research in 21st Century Art Museums, Louisiana Museum of Modern Art, Humblebæk, Denmark.

Simon, N. (2010). The participatory museum. Santa Cruz, CA: Museum 2.0. Retrieved from http://www.participatorymuseum.org/read

Solhjell, D. (2009). Kunstmuseet som læringsarena. Oslo, Norway: Nasjonalmuseet for kunst, arkitektur og design.

Statistics Norway. (2017). Norsk kulturbarometer. Retrieved from https://www.ssb.no/kulturbar

Steier, R. Pierroux, P., \& Krange, I. (2015). Embodied interpretation: Gesture, social interaction, and meaning making in a national art museum. Learning, Culture and Social Interaction, 7, 28-42. https://doi.org/10.1016/j.Icsi.2015.05.002

Uldall, A. G. (2016). Verktøykassa: Det kreative arbeidet med utstillinger $i$ Nasjonalmuseet. Oslo, Norway: Nasjonalmuseet.

Ulvik, M. (2016). Aksjonsforskning - en oversikt. In M. Ulvik, H. Riese, \& D. Roness (Eds.), A forske på egen praksis: Aksjonsforskning og andre tilnærminger til profesjonell utvikling i utdanningsfeltet (pp. 17-35). Bergen: Fagbokforlaget.

Ulvik, M., Riese, H., \& Roness, D. (Eds.). (2016). A forske på egen praksis: Aksjonsforskning og andre tilnærminger til profesjonell utvikling $i$ utdanningsfeltet. Bergen: Fagbokforlaget.

Walsh, V. (2016). Redistributing knowledge and practice in the art museum. Stedelijk Studies, 4. http://stedelijkstudies.com/journal/redistributing-knowledgepractice-art-museum/

Woon, W. (2019). Education for a new national museum: State-of-the-art in museum education. In B. Christensen-Scheel (Ed.), Education for a new museum (pp. 33-65). Oslo, Norway: Nasjonalmuseet for kunst, arkitektur og design. 